AGRITECH, Vol. 37, No. 1, Februari 2017, Hal. 30-37 DOI: http://dx.doi.org/10.22146/agritech.17004 ISSN 0216-0455 (Print), ISSN 2527-3825 (Online) Tersedia online di https://jurnal.ugm.ac.id/agritech/

\title{
Pemurnian Parsial dan Karakterisasi Enzim Xilanase dari Bakteri Laut Bacillus safencis strain LBF P20 Asal Pulau Pari Jakarta
}

\author{
Partial Purification and Characterization of Xylanase Enzyme from Marine Bacterium Bacillus safencis \\ strain LBF P20 from Pari Island Jakarta \\ F. Fitria', Sri Pujiyanto' Budi Raharjo', Nanik Rahmani ${ }^{2}$, Y. Yopi ${ }^{2}$ \\ ${ }^{1}$ Departemen Mikrobiologi, Fakultas Sains dan Matematika, Universitas Diponegoro, Jl. Prof. H. Soedarto, SH, \\ Tembalang Semarang, Jawa Tengah 50275, Indonesia \\ ${ }^{2}$ Laboratorium Biokatalis dan Fermentasi, Pusat Penelitian Bioteknologi, Lembaga Ilmu Pengetahuan Indonesia, \\ Jl. Raya Bogor, Km. 46 Cibinong-Bogor, Jawa Barat 16911, Indonesia \\ Email: yopi001@lipi.go.id
}

Submisi: 28 Desember 2015; Penerimaan: 8 Maret 2016

\begin{abstract}
ABSTRAK
Enzim xilanase (EC 3.2.1.8) digunakan dalam hidrolisis xilan (hemiselulosa) menjadi xilooligosakarida dan xilosa Penelitian ini bertujuan untuk melakukan purifikasi parsial dan karakterisasi xilanase dari bakteri laut Bacillus safencis strain LBF P20 serta uji hidrolisis untuk mengetahui jenis xilooligosakarida yang dihasilkan oleh enzim tersebut. Berdasarkan hasil penelitian, waktu optimum untuk produksi enzim terjadi pada jam ke 96 dengan aktivitas enzim sebesar 6,275 U/mL dan aktivitas spesifik enzim sebesar 5,093 (U/mg). Aktivitas spesifik enzim hasil pemekatan dengan amicon ${ }^{\circledR}$ ultra-15 centrifugal filter devices, kromatografi filtrasi gel dan kromatografi penukar anion mengalami peningkatan berturut-turut sebesar 15,1; 34,7 dan 96,0 U/mg. Hasil karakterisasi menunjukkan aktivitas tertinggi pada $\mathrm{pH} 7$, suhu $60^{\circ} \mathrm{C}$ dan stabil pada suhu $4{ }^{\circ} \mathrm{C}$. Analisis SDS-PAGE dan zimogram menunjukkan berat molekul protein xilanase berkisar $25 \mathrm{kDa}$. Jenis gula reduksi yang dihasilkan yaitu xiloheksosa, xilotriosa, dan xilobiosa.
\end{abstract}

Kata kunci: Bacillus safensis; pemurnian; karakterisasi; xilanase; xilooligosakarida

\begin{abstract}
Enzyme xylanase (EC 3.2.1.8) is widely used in various industrial fields for the hydrolysis of xylan (hemicellulose) into xylooligosaccharide and xylose. The aims of this study were to conduct partial purification-and characterization of xylanase from marine Bacillus safencis strain LBF P20 and to obtain the xylooligosaccharide types from xylan hydrolysis by this enzyme. Based on this research, the optimum time for enzyme production occurred at 96 hours with the enzyme activity of $6.275 \mathrm{U} / \mathrm{mL}$ and enzyme specific activity of $5.093 \mathrm{U} / \mathrm{mg}$. The specific activities were obtained

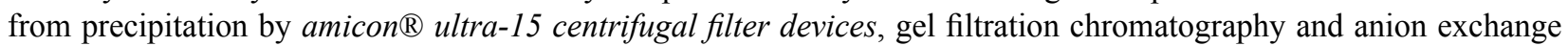
chromatography that were increased by $15.07,34.7$, and $96.0 \mathrm{U} / \mathrm{mg}$. The results showed that the highest activity at $\mathrm{pH}$ 7 , temperature of $60{ }^{\circ} \mathrm{C}$, and stable at $4{ }^{\circ} \mathrm{C}$. Type of xylooligosaccharide produced by this study were xylohexoses, xylotriose, and xylobiose. SDS-PAGE analysis and zimogram showed that the molecular weight of xylanase protein were about $25 \mathrm{kDa}$.
\end{abstract}

Keywords: Bacillus safencis; purification; characterization; xylanase; xylooligosaccharide 


\section{PENDAHULUAN}

Xilanase merupakan enzim yang berperan dalam hidrolisis xilan (hemiselulosa) menjadi xilooligosakarida dan xilosa (Susilowati, 2012). Selain berperan dalam menghasilkan xilooliogosakarida, xilanase juga banyak dibutuhkan di berbagai bidang industri, misalnya industri kertas, farmasi, etanol, pakan ternak, makanan, dan minuman (Beg dkk., 2001). Secara alami xilooligosakarida terdapat dalam buah-buahan, sayur-mayur, susu nabati, madu dan dapat diproduksi pada skala industri dari bahan hemiselulosa yang kaya xilan, dapat pula diperoleh dengan mengolah bahan limbah hasil hutan, pertanian atau limbah industri yang tinggi kandungan lignosellulosanya (Vaquez dkk., 2001). Di Indonesia, bahan-bahan limbah tersebut mudah didapat dan tersedia dalam jumlah yang banyak sehingga pemanfaatan limbah tersebut dengan bantuan enzim xilanase untuk produksi xilooligosakarida akan sangat menguntungkan baik secara ekologis maupun ekonomi. Xilooligosakarida mempunyai nilai penting untuk digunakan sebagai bahan prebiotik (Dominguez dkk., 2003).

Enzim xilanase dihasilkan oleh berbagai jenis organisme seperti bakteri, khamir, kapang, protozoa, dan siput. Bakteri adalah sumber enzim yang paling banyak digunakan. Produksi enzim dari bakteri memiliki keunggulan karena pertumbuhannya cepat, mudah ditumbuhkan, mudah diatur produksinya, dan mudah direkayasa secara genetika (Fawzya dkk., 2013). Penelitian produksi dan purifikasi xilanase dari bakteri darat maupun laut telah dilakukan oleh beberapa peneliti, seperti dari Fomitopsis pinicola (Keum dkk., 2010), Bacillus pumilus strain, GESF-1 (Menon dkk., 2010), Cellulosimicrobium sp. MTCC 10645 (Kamble dan Jadhav, 2012), Aspergillus awamori dan Aspergillus phoenicis (Mohamed dan Rashad, 2012), Bacillus brevis (Goswami dkk., 2013), Paenibacillus sp. NF1 (Zheng dkk., 2014). Pemanfaatan bakteri laut memberikan peluang untuk mendapatkan enzim yang unik karena bakteri laut mempunyai karakter yang spesifik, yaitu dapat bertahan pada salinitas tinggi, suhu, cahaya, dan lingkungan ekstrim lainnya sehingga diharapkan bakteri laut dapat beradaptasi dan bertahan meski dilingkungan yang ekstrim (Prasad, 2013).

Jumlah total sel bakteri di laut diperkirakan sebanyak $3,6 \times 10^{29} \mathrm{~g}$ dengan total kandungan karbon selulernya sebesar $3 \times 10^{17} \mathrm{~g}$ (Whitman dkk., 1998), oleh karena itu pemanfaatan bakteri laut yang melimpah berpotensi untuk dikembangkan dalam menghasilkan enzim xilanase. Bakteri laut Bacillus safencis strain LBF P20 yang diisolasi dari Pulau Pari, Jakarta telah dilaporkan dapat memproduksi xilanase dengan aktivitas enzim sebesar 4,06 U/mL pada waktu inkubasi 96 jam (Rahmani dkk., 2014).
Penelitian ini difokuskan untuk melakukan penelitian lanjutan yaitu purifikasi parsial enzim xilanase dari Bakteri laut Bacillus safencis strain LBF P20. Purifikasi dilakukan untuk mendapatkan enzim spesifik yang diinginkan sehingga dapat diketahui karakternya meliputi $\mathrm{pH}$, suhu, stabilitas, berat molekul serta jenis xilooligosakarida yang dihasilkan.

\section{METODE PENELITIAN}

\section{Mikroorganisme}

Bakteri laut strain LBF P20 diperoleh dari koleksi Laboratorium Biokatalis dan Fermentasi, Puslit Bioteknologi LIPI. Bakteri diremajakan dengan menginokulasi isolat dalam media padat ASW 3,8 \%, ekstrak khamir $0,1 \%$, pepton $0,5 \%$, agar $1,8 \%$, birchwood xilan (sigma) $0,5 \%$.

\section{Produksi Enzim Xilanase}

Produksi enzim dilakukan pada media yang terdiri atas $3,8 \%$ artificial sea water (ASW), $0,1 \%$ ekstrak khamir, $0,5 \%$ pepton, $0,5 \%$ laktosa, $0,5 \%$ urea. Erlenmeyer flasks 2L (2 Erlenmeyer) mengandung media kultur@ $@ 400 \mathrm{~mL}$ disuplementasi dengan 1,5\% ampas tebu diinokulasikan dengan media prekulture $4 \mathrm{~mL}$ dan diinkubasikan selama 120 jam pada Bio-shaker BR-43FL, Taitec-Jepang dengan kecepatan $150 \mathrm{rpm}$ selama 96 jam pada suhu $30{ }^{\circ} \mathrm{C}$. Kultur dipanen dengan cara sentrifugasi pada kecepatan 4000 rpm, suhu $4{ }^{\circ} \mathrm{C}$ selama 10 menit dan filtrat supernatan yang diperoleh diuji aktivitas xilanase dan kadar proteinnya.

\section{Aktivitas Xilanase}

Aktivitas enzim xilanase ditentukan dengan metode Bailey dkk (1992) dengan menggunakan xilan 0,5\% (w/v) dalam buffer fosfat $0,05 \mathrm{M}(\mathrm{pH}$ 7) selama 15 menit reaksi. Campuran reaksi terdiri atas $0,25 \mathrm{~mL}$ filtrat enzim dan substrat xilan $0,25 \mathrm{~mL}$ diinkubasi pada suhu $30^{\circ} \mathrm{C}$ selama 15 menit dan reaksi dihentikan dengan penambahan DNS $500 \mu \mathrm{L}$ (campuran reaksi akan berubah warna menjadi kuning orange) diikuti dengan pemanasan pada suhu 100 ${ }^{\circ} \mathrm{C}$ selama 10 menit. Jumlah gula reduksi yang terbentuk ditentukan dengan metode DNS (Miller, 1959) menggunakan standar xilosa (Sigma) dengan pengukuran absorbansi pada panjang gelombang $540 \mathrm{~nm}$. Satu unit (U) aktivitas xilanase didefinisikan sebagai jumlah enzim yang diperlukan untuk menghasilkan $1 \mu \mathrm{mol}$ xilosa per menit dibawah kondisi reaksi. Substrat tanpa enzim digunakan sebagai kontrol reaksi.

\section{Uji Kadar Protein}

Penentuan kadar protein dilakukan dengan metode folin phenol dengan bovine serum albumin (BSA) sebagai standar (Lowry dkk., 1951). Kadar protein diukur dengan 
menggunakan UV mini-1240, UV-VIS spektrofotometer (Shimadzu, Jepang) pada panjang gelombang $280 \mathrm{~nm}$.

\section{Pemurnian Partial Xilanase}

Enzim xilanase yang diproduksi dalam penelitian ini termasuk jenis enzim ekstraseluler. Tahap pertama pemurnian parsial adalah menghilangkan beberapa pengotor seperti karbohidrat dan memekatkan enzim ekstra kasar xilanase dengan menggunakan amicon ${ }^{\circledR}$ ultra-15 centrifugal filter devices (Merck Millipore). Sebanyak $10 \mathrm{~mL}$ ekstrak kasar enzim dimasukkan ke dalam falcon amicon $(50 \mathrm{~mL})$ dan disentrifuse (TOMY MX-307, high speed refrigerated micro centrifuge- Jepang) dengan kecepatan 4000 g pada suhu 4 ${ }^{\circ} \mathrm{C}$. Bagian pengotor akan turun ke bagian bawah dan ekstrak kasar enzim akan terkonsentrat dibagian atas, sebanyak $1 \mathrm{~mL}$. Ekstrak kasar enzim tersebut selanjutnya diuji kadar protein dan aktivitas enzimnya.

Selanjutnya, pemurnian dilakukan menggunakan kromatografi filtrasi gel dan kromatografi penukar ion. Pemurnian dengan filtrasi gel menggunakan matriks sephadex G-75. Matriks dimasukkan secara perlahan kedalam kolom kromatografi. Volume xilanase yang dimurnikan sebanyak 0,5 mL. Sampel protein dialirkan kedalam kolom kemudian matriks sephadex G-75 (GE Healthcare) dielusi menggunakan buffer fosfat $0,02 \mathrm{M}$ sehingga diperoleh beberapa fraksi dengan volume masing-masing fraksi sebanyak $1 \mathrm{~mL}$ dan diukur kadar protein dan aktivitas enzimnya untuk penentuan aktivitas enzim spesifik.

Pemurnian dengan kromatografi penukar anion dilakukan menggunakan AKTAPrimePlus (GE Healthcare) dengan metode ion exchange chromatography. Kolom yang digunakan yaitu kolom penukar anion HiTrapQ SepharoseFast Flow (GE Healthcare). Fraksi yang ditampung sebanyak $1 \mathrm{~mL} / \mathrm{menit}$ pada setiap tabung, dilanjutkan diukur kadar protein dan aktivitas enzimnya untuk penentuan aktivitas enzim spesifik.

\section{Penentuan Berat Molekuler dengan SDS-PAGE dan Zymogram}

Penentuan berat molekul dilakukan dengan menggunakan metode Laemmli (1970) dengan konsentrasi akrilamida $10 \%$ dan marker Pricision Plus Protein Dual Color Standards (Biorad). Sebanyak $10 \mu \mathrm{L}$ sampel (ekstrak enzim kasar), enzim hasil pemekatan dan hasil pemurnian kromatografi masing-masing dirunning pada elektrophoresis gel akrilamida. Proses elektroforesis berlangsung selama 2 jam pada tegangan 100 volt dan $50 \mathrm{~mA}$. Hasil SDS-PAGE diwarnai dengan pewarna coomasie brilliant blue. Sedangkan hasil zymogram diwarnai dengan perendaman secara bertahap pada miliQ, Triton-X, $50 \mathrm{mM}$ buffer fosfat $\mathrm{pH} \mathrm{7,} \mathrm{congo} \mathrm{red,}$ $\mathrm{NaCl} 1 \mathrm{M}$ dan asam asetat $0,5 \%$.

\section{Karakterisasi Enzim}

\section{Pengaruh pH dan suhu terhadap aktivitas xilanase}

Pengaruh $\mathrm{pH}$, suhu, dan stabilitas xilanase diukur dalam campuran reaksi $0,25 \mathrm{~mL}$ xilan dan $0,25 \mathrm{~mL}$ enzim hasil pemurnian parsial dalam kisaran $\mathrm{pH} 4,0-8,0$. Bufer yang

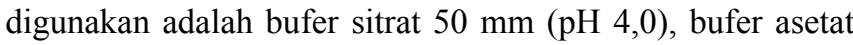
$50 \mathrm{~mm}(\mathrm{pH} \mathrm{5,0)}$ dan bufer fosfat $50 \mathrm{~mm}(\mathrm{pH} \mathrm{6,0-7,0)} \mathrm{dan}$ buffer glisin- $\mathrm{NaOH} 50 \mathrm{mM}$ (pH 7,0-9,0). Campuran enzim direaksikan pada suhu ruang selama 15 menit. Pengaruh perbedaan suhu pada aktivitas xilanase diukur dengan menggunakan $\mathrm{pH}$ optimum yang sudah diperoleh pada tahap sebelumnya dan diinkubasi pada suhu $30{ }^{\circ} \mathrm{C}$ sampai $80{ }^{\circ} \mathrm{C}$ selama 15 menit. Stabilitas xilanase terhadap suhu dilakukan pada suhu $4{ }^{\circ} \mathrm{C}, 30{ }^{\circ} \mathrm{C}, 60{ }^{\circ} \mathrm{C}$ pada interval waktu yang berbeda dari $0,1,2,3,4,5$ dan 24 jam dengan menggunakan buffer fosfat $\mathrm{pH} 7$.

\section{Hidrolisis xilan dengan enzim murni parsial dari Bacillus safencis strain LBF $\mathrm{P} 20$}

Hidrolisis dilakukan pada substrat xilan 0,5\% dengan menggunakan enzim hasil pemurnian parsial dengan kromatografi penukar anion pada kondisi optimum $\left(60{ }^{\circ} \mathrm{C}\right.$, $\mathrm{pH}$ 7) selama 5 jam. Sampel hasil hidrolisis disentrifuge pada kecepatan $7000 \mathrm{rpm}$, suhu $4^{\circ} \mathrm{C}$. Supernatan dianalisis jenis xilooligosakarida yang terbentuk dengan menggunakan HPLC dengan sistem kolom pengemas Hiplex Ca (Duo) (6.5 ID x $300 \mathrm{~mm}$ ), eluen aquades atau miliQ $\mathrm{H}_{2} \mathrm{O} 100 \%$, suhu $85^{\circ} \mathrm{C}$, laju alir $0,6 \mathrm{~mL} / \mathrm{min}$ dengan detektor refractive index detector (RID).

\section{HASIL DAN PEMBAHASAN}

\section{Produksi Xilanase}

Produksi enzim xilanase dari bakteri Bacillus safencis strain LBF P20 dilakukan pada kondisi yang diperoleh pada tahap penelitian sebelumnya oleh (Rahmani dkk., 2014). Sebanyak $800 \mathrm{~mL}$ ekstrak enzim kasar diperoleh pada waktu panen jam ke 96 dengan aktivitas enzim sebesar 6,278 U/mL.

\section{Pemurnian Parsial}

Tingkat kemurnian suatu enzim diketahui dari aktivitas spesifik enzim tersebut, semakin tinggi aktivitas spesifik suatu enzim maka enzim akan semakin murni (Su'i dan Suprihana, 2013). Berdasarkan hasil yang diperoleh, xilanase dari bakteri Bacillus safencis strain LBF P20 memiliki aktivitas spesifik yang cukup besar $(5,093 \mathrm{U} / \mathrm{mg})$. Hasil penelitian tersebut hampir sama dengan aktivitas spesifik yang diperoleh dari Fomitopsis pinicola yaitu sebesar 5,4 U/mg (Keum dkk., 2010) dan 5,3 U/mg dari Bacillus pumillus GESF (Menon 
dkk., 2010). Sedangkan jika dibandingkan dengan Gupta dkk. (2000), nilai aktivitas spesifik dari Bacillus safencis strain LBF P20 jauh lebih besar dibandingkan aktivitas spesifik dari Staphylococcus sp. SG-13, yaitu sebesar 0,23 U/mg. Namun xilanase yang diperoleh merupakan enzim ekstrak kasar yang masih terdapat komponen-komponen pengotor sehingga perlu dilakukan pemurnian untuk mendapatkan enzim spesifik yang diinginkan.

Tahap pertama proses pemurnian adalah pengendapan enzim dengan menggunakan amicon ${ }^{\circledR}$ ultra-15 centrifugal filter devices (Merck Millipore) menghasilkan aktivitas enzim sebesar 41,19 $\mathrm{U} / \mathrm{mL}$ dengan aktivitas spesifik sebesar 15,07 U/mg. Kemurnian meningkat 3 kali lipat dari enzim ekstrak kasar dan menghasilkan yield sebesar $82 \%$ (Tabel 1). Hasil tersebut hampir sama dengan yang diperoleh oleh Gupta dkk. (2010) yang melakukan pengendapan dengan (NH4)2SO4 (50-80\%) diperoleh yield sebesar $85 \%$ dari Staphylococcus sp. SG-13 dan lebih besar berturut-turut 52,03\% dari Cellulosimicrobium sp. MTCC 10645 (Kamble dan Jadhav, 2010); 25,8 \% Bacillus pumillus GESF-1 (Menon 2010); $65 \%$ dari Bacillus brevis (Goswam dkk., 2013); 75,09 $\%$ dari Paenibacillus sp. NF1. (Zheng dkk., 2014); 58,92\% dari S. cyaneus SN32 (Ninawe dkk., 2008) dan sangat jauh lebih besar dengan menggunakan ultrafiltration (PES30) $F$. pinicola KMJ812. 13 \% (Keum dkk., 2010). Enzim pekat inilah yang kemudian dilanjutkan ke tahap pemurnian dengan kromatografi filtrasi gel.

Pemurnian enzim xilanase selanjutnya dilakukan dengan pemisahan protein berdasarkan berat molekul dengan kromatografi filtrasi gel dan pemisahan protein berdasarkan muatannya dengan kromatografi penukar ion. Hasil pemurnian xilanase dengan kromatografi filtrasi gel ditunjukkan pada Gambar 1. Hasil yang diperoleh menunjukkan adanya 3 puncak protein dan 1 puncak aktivitas enzim. Adanya 3 puncak protein menandakan pemisahan protein berdasarkan ukuran partikelnya. Fraksi tersebut kemudian diuji aktivitas enzim dan menunjukkan bahwa aktivitas enzim xilanase mulai meningkat pada fraksi ke-15 sampai fraksi ke-22 dan menurun pada fraksi ke-23. Hal ini menunjukkan bahwa

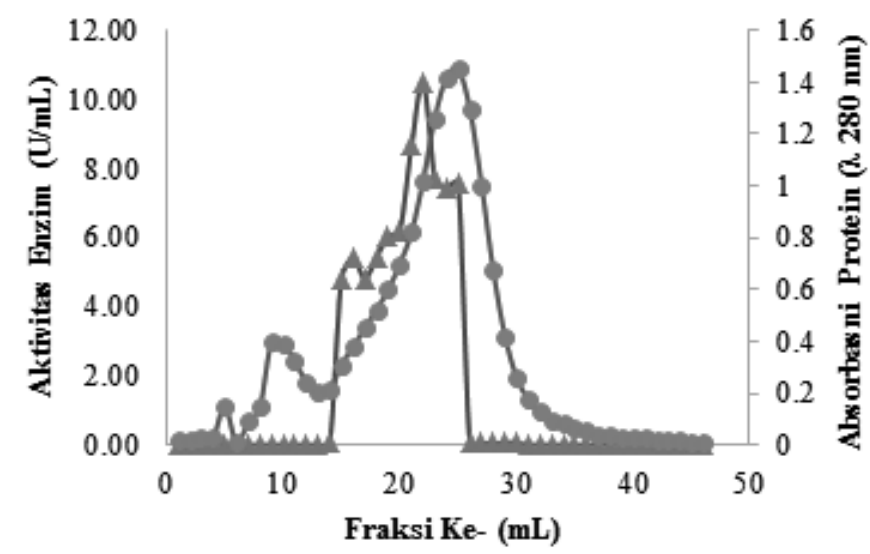

\section{$\longrightarrow$ Aktivitas enxim $\quad \longrightarrow$ Kadar Protein}

Gambar 1. Aktivitas xilanase dan kadar protein 60 fraksi hasil pemurnian kromatografi filtrasi gel menggunakan sephadex G75 dengan kecepatan aliran $1 \mathrm{~mL} /$ menit yang dielusi oleh $0,02 \mathrm{M}$ buffer fosfat $\mathrm{pH} 7$

pada puncak tersebut memiliki aktivitas enzim xilanase dan selanjutnya fraksi-fraksi tersebut dikumpulkan $( \pm 7 \mathrm{~mL})$ dan diendapkan kembali dengan amicon ${ }^{\circledR}$ ultra-15 centrifugal filter devices (Merck Millipore) kemudian dimurnikan dengan kromatografi penukar anion.

Hasil pemurnian xilanase dengan kromatografi penukar anion menunjukkan adanya dua puncak protein yang terpisah pada fraksi ke-15 dan ke-22 yang ditunjukkan pada Gambar 2. Hal ini menandakan adanya protein yang terpisah berdasarkan muatan ion nya sehingga pada grafik terlihat adanya peningkatan kadar protein $(280 \mathrm{~nm})$ dibeberapa fraksi secara drastis. Setiap fraksi kemudian diukur aktivitas xilanasenya dan pada fraksi ke-16 memiliki aktivitas xilanase sebesar $0,316 \mathrm{U} / \mathrm{mL}$. Aktivitas spesifik, yield (\%), dan kelipatan kemurnian pada setiap tahapan pemurnian ditunjukkan pada Tabel 1.

Berdasarkan (Tabel 1), aktivitas spesifik dari tahapan satu ketahapan selanjutnya mengalami peningkatan. Xilanase murni yang didapat pada akhir proses pemurnian memiliki nilai aktivitas spesifik sebesar 96,0 U/mg dan memiliki

Tabel 1. Aktivitas spesifik, yield (\%) dan kelipatan kemurnian pada setiap tahapan pemurnian enzim xilanase dari Bacillus safencis strain LBF P20 dengan substrat bagas 1,5\%

\begin{tabular}{lrrrrrrr}
\hline \multicolumn{1}{c}{ Nama } & Vol $(\mathrm{mL})$ & $\begin{array}{c}\text { Aktivitas } \\
(\mathrm{U} / \mathrm{mL})\end{array}$ & $\begin{array}{c}\text { Aktivitas } \\
\text { Total }(\mathrm{U})\end{array}$ & $\begin{array}{c}\text { Protein } \\
(\mathrm{mg})\end{array}$ & $\begin{array}{c}\text { Aktivitas } \\
\text { Spesifik }(\mathrm{U} / \mathrm{mg})\end{array}$ & $\begin{array}{c}\text { Yield } \\
(\%)\end{array}$ & $\begin{array}{c}\text { Kelipatan } \\
\text { Kemurnian }\end{array}$ \\
\hline Enzim Ekstrak Kasar & 20 & 6,278 & 125,560 & 24,650 & 5,093 & 100 & 1 \\
Amicon & 2,5 & 41,190 & 102,975 & 6,830 & 15,070 & 82 & 3 \\
Kromatografi Filtrasi Gel & 0,5 & 8,338 & 4,169 & 0,120 & 34,741 & 3,3 & 6,8 \\
Kromatografi Penukar Anion & 0,3 & 0,64 & 0,192 & 0,002 & 96,000 & 0,2 & 18,8 \\
\hline
\end{tabular}




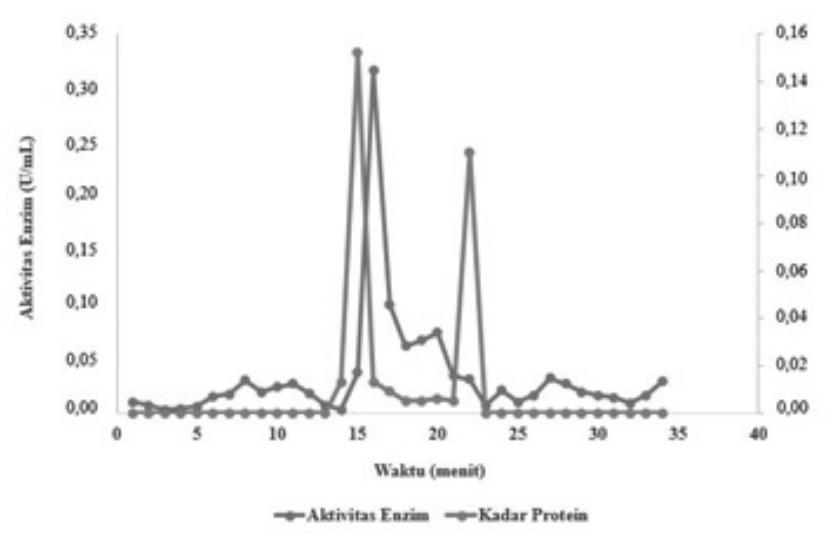

Gambar 2. Aktivitas xilanase dan kadar protein dari 35 fraksi hasil pemurnian kromatografi penukar anion dengan kecepatan aliran $1 \mathrm{~mL} /$ menit yang dielusi oleh $0,05 \mathrm{M}$ Buffer Tris-Cl $\mathrm{pH}$ 7,6

tingkat kemurnian 18,8 kali dari enzim ekstrak kasarnya. Nilai aktivitas spesifik serta tingkat kemurnian pada final purifikasi xilanase dari beberapa bakteri lainnya sangat beragam jika dibandingkan dengan hasil penelitian ini, tergantung jenis bakteri, kolom kromatograpfi yang digunakan, seperti purifikasi dengan menggunakan Sephadex G-100 dari Staphylococcus sp. SG-13 menghasilkan aktivitas spesifik 2,74 dengan tingkat kemurnian 12 (Gupta dkk., 2000), kromatografi DEAE-sepharose dari S. cyaneus SN32 menghasilkan aktifitas spesifik $893.56 \mathrm{U} / \mathrm{mg}$ dengan tingkat kemurnian 2.254 (Ninawe dkk., 2008), Q-Sepharose dari Paenibacillus sp. NF1. yaitu 3.081,05 dengan tingkat kemurnian 14,55 (Keum dkk., 2010), gel permeation dari Bacillus pumillus GESF-1 yaitu 112,42 dengan tingkat kemurnian 21,21 (Menon dkk., 2010), DEAE Sepharose dari Bacillus brevis yaitu 4.380 dengan tingkat kemurnian 9,6 (Goswam dkk., 2013), DEAE Cellulose dari Cellulosimicrobium sp. MTCC 10645 yaitu 246,6 dengan tingkat kemurnian 16,2 (Kamble dan Jadhav, 2010), monoQ ion-exchange chromatography dari $F$. pinicola KMJ812 sebesar 74,4 dengan tingkat kemurnian 13,8 (Keum dkk.,2010). Semakin murni enzim maka akan semakin besar nilai aktivitas spesifik dan semakin efisien juga enzim bekerja karena jumlah protein (mg) semakin kecil namun laju reaksi tetap sama atau meningkat karena berkurangnya interferensi dari inhibitor enzim. Sedangkan yield yang dihasilkan dari penelitian ini dengan menggunakan kromatografi filtrasi gel sebesar 3,3\% dan penukar anion 0, $2 \%$. Teknik pemurnian yang sama telah dilaporkan oleh Goswami dkk (2013) yang melakukan pemurnian enzim xilanase dengan kromatografi filtrasi gel dengan Sephadex G 50 dan kromatografi penukar ion DEAE Sepharose dari Bacillus brevis diperoleh yield masing-masing $8,4 \%$ dan $2,4 \%$.

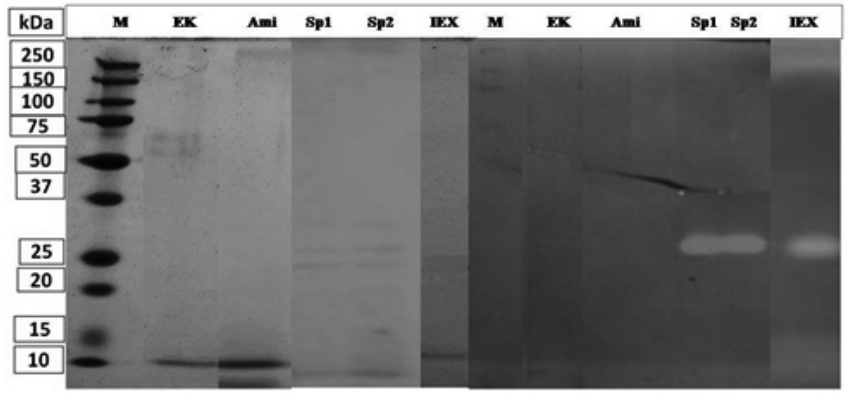

Gambar 3. Hasil elektroforesis setiap tahapan pemurnian yang ditandai dengan munculnya pita protein sebagai berat molekul (Ket : $\mathrm{M}=$ Marker $; \mathrm{Ek}=$ Enzim kasar; Am=Amicon; sp1= Pemurnian dengan kromatografi filtrasi gel dengan sephadex G-75tahap 1; sp2= Pemurnian dengan kromatografi filtrasi gel dengan sphadex G-75 tahap 2; IEX= Pemurnian dengan Ion exchange Cromatography)

Hasil elektroforesis menunjukkan xilanase pada enzim ekstrak kasar terlihat adanya smear. Hal ini menandakan pada xilanase ekstrak kasar masih terdapat banyak jenis protein sehingga masih perlu dilakukannya pemurnian. Hasil pita protein yang didapat pada tahapan pemurnian dengan kromatografi filtrasi gel menggunakan sephadex G-75 $\left(\mathrm{sp}_{1}\right.$ dan $\mathrm{sp}_{2}$ ) dan kromatografi penukar anion menunjukkan adanya 2 jenis xilanase dengan berat molekul antara 20 dan $25 \mathrm{kDa}$. Hasil elektroforesis ditunjukkan pada Gambar 3. Nilai tersebut hampir sama dengan hasil SDS-PAGE enzim xilanase hasil pemurnian dari Bacillus subtilis ASH dengan berat molekul 23 kDa (Sanghi dkk., 2010), dari Streptomyces cyaneus SN32 dengan berat molekul 20.5 k Da (Ninawe dkk., 2007).

Data pemurnian enzim yang diperoleh melalui SDS-PAGE tidak selalu menunjukkan katalitik enzim sebenarnya karena adanya kontaminan, isoenzim, atau enzim lain. Kekurangan ini dapat diatasi dengan meneliti aktivitas enzim dengan zimogram (Leber dan Balkwil, 1997). Ekspresi pada zimogram muncul pada tahapan pemurnian kromatografi filtrasi gel $\left(\mathrm{sp}_{1}\right.$ dan $\left.\mathrm{sp}_{2}\right)$ dan pada kromatografi penukar anion yang terletak berkisar $25 \mathrm{kDa}$. Hal ini menandakan bahwa pita protein dengan berat molekul pada kisaran $25 \mathrm{kDa}$ yang muncul pada SDS PAGE merupakan protein xilanase yang dapat dibuktikan dengan munculnya pita pada tahapan zimogram.

Karakterisasi meliputi variasi $\mathrm{pH}$, suhu, dan stabilitas pada beberapa suhu. Hasil karakterisasi $\mathrm{pH}$ optimum ditunjukkan pada Gambar 4. Hasil karakterisasi xilanase menunjukkan bahwa aktivitas xilanase tertinggi pada $\mathrm{pH} 7$ sebesar 1,151 U/mL. Hal ini disebabkan pada $\mathrm{pH}$ tersebut enzim mempunyai muatan yang mendukung kestabilan 


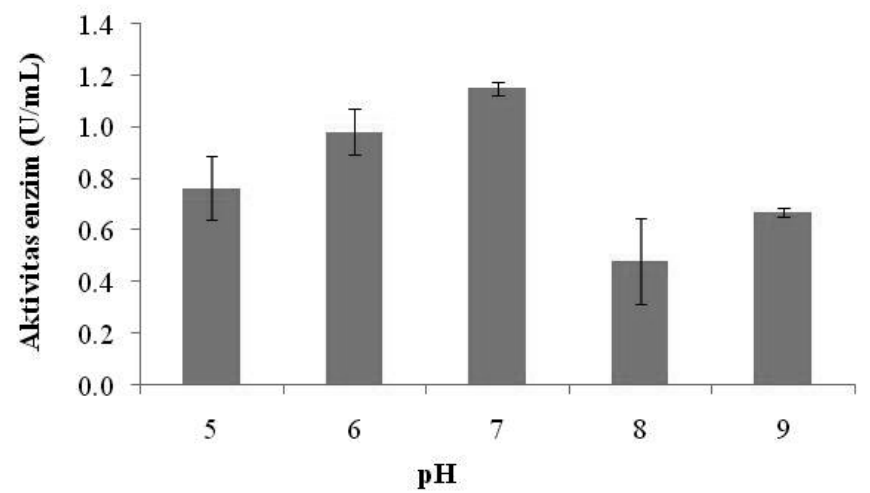

Gambar 4. Aktivitas xilanase Bacillus safencis strain LBF P20 dengan substrat beechwood xilan $0,5 \%$ pada variasi $\mathrm{pH}$ menggunakan $0,05 \mathrm{~mm}$ buffer asetat (pH 4 dan 5) $0.05 \mathrm{~mm}$ bufer fosfat ( $\mathrm{pH}$ dan 7), dan $0,05 \mathrm{~mm}$ buffer Tris- $\mathrm{HCl}(\mathrm{pH} 8$ dan 9)

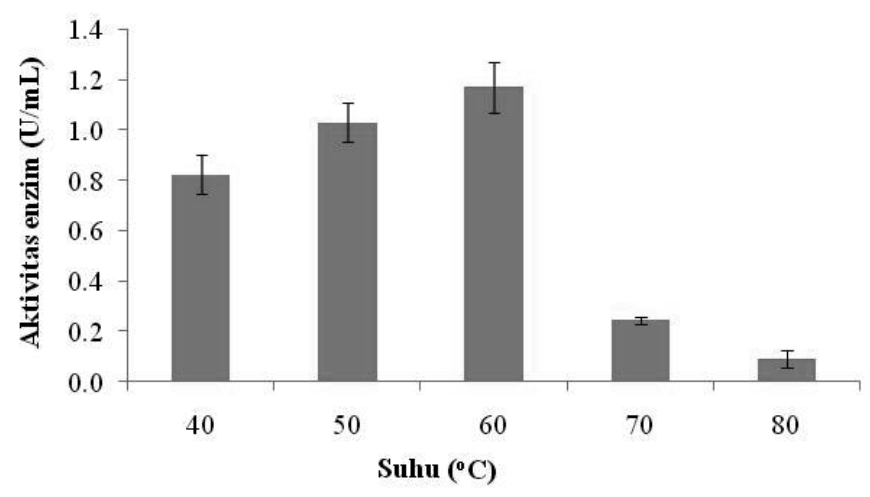

Gambar 5. Aktivitas xilanase Bacillus safencis strain LBF P20 dengan substrat beechwood xilan $0,5 \%$ pada suhu $40,50,60,70,80^{\circ} \mathrm{C}$ dengan $\mathrm{pH} 7$ menggunakan $0,05 \mathrm{~mm}$ buffer fosfat 7 .

struktur enzim (Bommarius dan Broering, 2005). Aktivitas optimum xilanase yang dihasilkan oleh mikroba asal lingkungan laut umumnya pada kisaran $\mathrm{pH}$ 7-9 atau pada suasana netral-basa (Fawzya, 2013). Aktivitas enzim xilanase pada $\mathrm{pH}$ optimum 7.0 serupa dengan penelitian yang dilakukan oleh Gupta dkk. (1999) bahwa enzim xilanase yang diperoleh dari Bacillus sp. NG-27 memiliki pH optimum 7.0 yang stabil pada kisaran 6.0-10.0.

Faktor lain yang mempengaruhi aktivitas katalitik enzim adalah suhu. Xilanase dari Bacillus safencis strain LBF P20 memiliki aktivitas enzim tertinggi pada suhu $60{ }^{\circ} \mathrm{C}$ sebesar $1,170 \mathrm{U} / \mathrm{mL}$. Hasil karakterisasi xilanase dengan penentuan suhu optimum ditunjukkan pada Gambar 5.

Hasil karakterisasi $\mathrm{pH}$ dan suhu dari enzim hasil pemurnian parsial ini sama dengan penelitian (Rahmani dkk., 2014) yang malakukan karakterisasi enzim xilanase ekstrak kasarnya dari Bacillus safencis strain LBF P20 memiliki aktivitas optimum pada $\mathrm{pH} 7$ dan suhu $60^{\circ} \mathrm{C}$, sehingga enzim

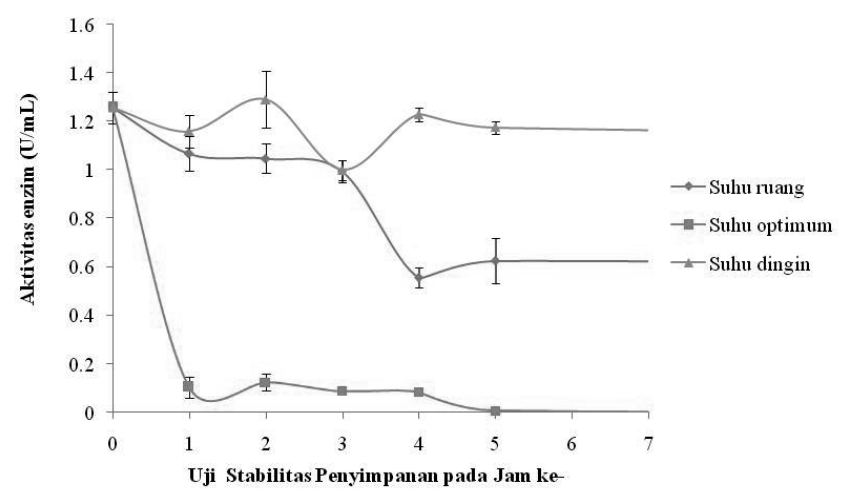

Gambar 6. Stabilitas enzim xilanase berdasarkan aktivitas enzim dari Bacillus safencis strain LBF P20 dengan 0,5\% beechwood xilan selama masa penyimpanan pada suhu ruang $\left( \pm 30^{\circ} \mathrm{C}\right)$, optimum $\left(60^{\circ} \mathrm{C}\right)$, dan dingin $\left(4^{\circ} \mathrm{C}\right)$.

ini tergolong termoenzim karena memiliki aktivitas optimum di dalam kisaran suhu $45-80{ }^{\circ} \mathrm{C}$ (Nam, 2004). Hasil yang diperoleh pada penelitian ini sesuai dengan hasil penelitian (Septianingrum, 2011) dimana xilanase dari Bacillus sp. mempunyai kisaran suhu optimum antara $50-70{ }^{\circ} \mathrm{C}$ pada $\mathrm{pH}$ 6-10.

Hasil pengujian stabilitas xilanase terhadap suhu inkubasi ditunjukkan pada Gambar 6. Hasil uji stabilitas penyimpanan menunjukkan bahwa enzim xilanase yang disimpan pada suhu dingin $\left({ }^{\circ} \mathrm{C}\right)$ jauh lebih stabil dibanding enzim yang disimpan pada suhu ruang dan suhu optimum. Hasil penelitian ini berbeda dengan xilanase dari B.brevis yang stabil selama dua jam pada suhu $55^{\circ} \mathrm{C}$ dan kehilangan aktivitas 5-10 \% setelah 20 menit (Goswam dkk., 2013), xilanase dari Bacillus subtilis ASH kehilangan aktivitas setelah suhu $45^{\circ} \mathrm{C}$ (Sanghi dkk., 2010). Penggunaan suhu rendah (bukan suhu pembekuan) dalam penyimpanan enzim dapat membantu menjaga kestabilan enzim karena lebih sedikitnya kemungkinan terjadi denaturasi akibat perubahan suhu yang merusak struktur tiga dimensi enzim. Kecepatan reaksi pada hampir semua enzim meningkat dua kali lipat setiap kenaikan suhu sebesar $10^{\circ} \mathrm{C}$. Suhu akan mempengaruhi energi kinetik molekul. Seiring dengan meningkatnya suhu, energi kinetik yang terjadi akan semakin tinggi yang ditandai dengan meningkatkanya frekuensi tumbukan antar molekul sehingga dapat meningkatkan laju reaksi (Murray dkk., 2009).

\section{Hidrolisis Xilan dengan Enzim Parsial Murni dari Bacillus safencis strain LBF P20}

Hidrolisis xilan menggunakan enzim xilanase hasil pemurnian parsial dianalisis menggunakan HPLC menunjukkan adanya puncak dengan retention time berturutturut 5,654 (xiloheksosa), 6,854 (xilotriosa), dan 7,914 (xilobiosa). Adanya puncak yang muncul pada analisis ini 


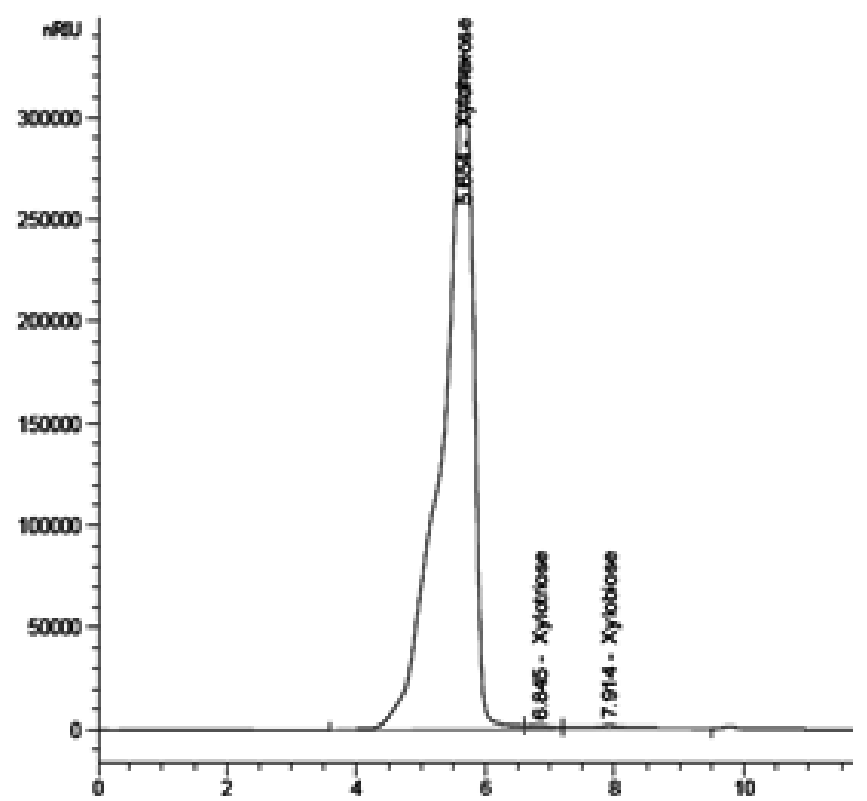

Gambar 7. Retention time pada HPLC sampel hasil hidrolisis xilan oleh xilanase yang telah dimurnikan pada penelitian ini.

menandakan terjadinya hidrolisis substrat xilan oleh xilanase menghasilkan gula-gula tersebut. Hasil hidrolisis yang dianalisa menggunakan HPLC ditunjukkan pada Gambar 7. Produk xilooligosakarida serupa dihasilkan oleh xilanase dari Cellulosimicrobium sp. MTCC 10645 yang menghasilkan xilobiosa dan xilotriosa (Kamble dan Jadhav, 2010). Sedangkan xilanase yang dihasilkan oleh Paenibacillus sp. NF1 menghasilkan produk xilooligosakarida dari xilosa sampai xilopentaosa (Zheng dkk., 2014).

\section{KESIMPULAN}

Produksi ekstrak enzim kasar xilanase yang dihasilkan oleh Bacillus safencis strain LBF P20 sebanyak $800 \mathrm{~mL}$ memiliki aktivitas enzim sebesar 6,278 U/mL. Aktivitas spesifik enzim dan tingkat kemurnian enzim xilanase meningkat seiring dengan tahapan pemurnian. Aktivitas spesifik enzim xilanase ekstrak kasar, pemekatan amicon ${ }^{\circledR}$ ultra-15 centrifugal filter devices (Merck Millipore), kromatografi filtrasi gel dan kromatografi penukar anion berturut-turut sebesar 5,1 , 15,1, 34,7 dan 96,0 U/mg. Tingkat kemurnian enzim pada tahap akhir meningkat 18,8 kali lipat dari enzim ekstrak kasar dengan berat molekul berkisar 25 kDa. Enzim xilanase murni yang diperoleh memiliki kondisi reaksi optimum pada $\mathrm{pH} 7$, suhu $60^{\circ} \mathrm{C}$ dan stabil pada suhu dingin $\left(4^{\circ} \mathrm{C}\right)$. Jenis xilooligosakarida yang dihasilkan berupa xilobiosa, xilotriosa, dan xiloheksosa.

\section{UCAPAN TERIMA KASIH}

Penelitian ini didanai oleh DIPA Tematik dan Kegiatan Unggulan Pangan dan Obat, Pusat Penelitian Bioteknologi, Lembaga Ilmu Pengetahuan Indonesia (LIPI).

\section{DAFTAR PUSTAKA}

Bailey, M.J., Biely, P. dan Poutanen, K. (1992). Interlaboratory testing of methods for assay of xylanase activity. Journal of Biotechnology 23: 257-270.

Beg, Q.K., Kapoor, M., Mahajan, L. dan Hoondal, G.S. (2001). Microbial xylanases and their industrial applications: a review. Application Microbiology and Biotechnology 56: 326-338.

Bommarius, A.S. dan Broering, J.M. (2005). Evaluation of hofmeister effects on the kinetic stability of proteins. The Journal of Physical Chemistry B 109: 20612-20619.

Dominguez, H., Alanso J.L., Garrote G., Carlos J. (2003). Xilooligosaccharides: propertis and technologies electron. Journal Environment Agriculture Food Chemistry 2(1): 1579-4377.

Fawzya, Y.N. (2013). Produksi dan karakterisasi xilanase dari isolat bakteri M-13.2a asal air laut Manado. Jurnal Kementrian Kelautan dan Perikanan 8: 1-8.

Goswami, G., Pathak, R.R., Krishnamohan, M. dan Ramesh, B. (2013). Production, partial purification and biochemical characterization of thermostable xylanase from Bacillus brevis Biomedical and Pharmacology Journal 6(2): 435-440.

Gupta, S., Bhushan, B. dan Hoondal, G.S. (2000). Isolation, purification and characterization of xylanase from Stapylococcus sp. SG-13 and its application in bioblenching of kraft pulp. Journal of Applied Microbiology 88: 325-334.

Kamble, R.D. dan Jadhav, A. (2012). Production, purification and characterisation of alkali stable xylanase from Cellulosimicrobium sp. MTCC 10645. Asian Pacific Journal of Tropical Biomedicine 2(3): S1790-S1797.

Keum, S., Marimuthu, J., Jung-Kul, L. dan YeongSuk, K. (2010). Purification and characterization of a thermostable xylanase from purification and characterization of a thermostable xylanase from Fomitopsis pinicola. Journal of Microbiology and Biotechnology 20(10): 1415-1423. 
Laemmli, U.K. (1970). Cleavage of structural proteins during assembly of the head of bacteriophage T4. Nature 227: 680-685.

Leber dan Balkwil (1997). Zymography: A single-step staining method for quantitative of proteolytic activity on substrat gels. Analysis Biochemistry 249: 24-28.

Lowry, O.H., Rosebrough, N.J., Farr, A.C. dan Randall, R. J. (1951). Protein measurement with folin phenol reagent. The Journal of Biological Chemistry 193: 265-275.

Menon, G., Kalpana, M., Jitendra, K. dan Bhavanath, J. (2010). Isolation, purification, and characterization of Haloalkaline xylanase from a Marine Bacillus pumilus strain GESF-1. Biotechnology and Bioprocess Engineering 15: 998-1005.

Miller, G.L. (1959). Dinitrosalysilic assay. Analysis Chemistry 31: 426-428.

Mohamed, S.A. dan Al-Hindi, R.R. (2012). Partial purification and characterization of xylanases from Aspergillus awamori and Aspergillus phoenicis. African Journal of Microbiology Research 23: 5025-5034.

Murray, R.K., Granner, D.K., Rodwell, V.W. (2009). Biokimia Harper. Pendit BU, penerjemah. EGC, Jakarta.

Nam, E.S. (2004). Â-galactosidase gene of thermus thermophulus KNOUC11 isolated from hot springs of a volcanie area in New Zealand identification of the bacteria cloning and expression of the gene in Escherchia coli. Asian-Aus Journal Animal Science 17:1591-1598.

Ninawe, S., Mukesh, K. dan Ramesh, C.K. (2008). Purification and characterization of extracellular xylanase from Streptomyces cyanus SN32. Bioresource Technology 99: 1252-1258.

Prasad, M.P. (2013). Screening for xylanase producing microorganisms from marine source. International Jurnal Microbiology Application Science 2(12): 489492.

Rahmani, N., Rabbani, N.U.J., Suparto, I.H. dan Yopi. (2014). Optimization of production xylanase from marine bacterium Bacillus safensis P20 on sugarcane baggase by submerged fermentation. International Jurnal on Advanced Science Engineering Inform Technology 4(6): 2088-5334.
Sanghi, A., Neelam, G., Gupta, V.K., Ashwani, M., Kuhad, R.C. (2010). One-step purification and characterization of cellulase-free xylanase produced by alkalophilic Bacillus subtilis ash. Brazilian Journal of Microbiology 41: 467-476.

Septianingrum, K. (2011). Produksi xilanase dari tongkol jagung dengan sistem bioprosesmenggunakan Bacillus circulans untuk pra-pemutihan pulp. Jurnal RisetIndustri 5(1): 87-97.

Su'i, M. dan Suprihana (2013). Fraksinasi enzim lipase dari endosperm kelapa dengan metode salting out. Jurnal Agritech 33(4): 377-383.

Susilowati, P.E., Raharjo, S., Desi, K. (2012).Produksi xilanase dari isolat sumber air panas sonai, Sulawesi Tenggara menggunakan limbah pertanian. Jurnal Natur Indonesia 14(3): 24-35.

Vaquez, M.J., Alonso, J.L., Dominguez dan Parajo, D.C. (2001). Xylooligosaccharides: manufacture and application. Jurnal Food Science and Technology 11: 387-93.

Whitman, W.B. (1998). Prokaryotes: the unseen majority. Proceedings of the National Academy of Sciences of the United States of America 95: 6578-6583.

Zheng, H., Ming-zhe, S., Ling-cai, M., Haisheng, P., Xiu-qing, Z., Zheng, Y. Wen-hui, Z., Jing-sheng, Z., Jin-rong, H., Fu-ping, L., dan Jun-she, S. (2014). Purification and characterization of a Thermostable xylanase from Paenibacillus sp. NF1 and its application in xylooligosaccharides production. Journal of Microbiology and Biotechnology 24(4): 489496.

Zusfahair, Setyaningtyas, T. dan Fatoni, A. (2010). Isolasi, pemurnian dan karakterisasi lipase bakteri hasil skrining dari tanah tempat pembuangan akhir (TPA) Gunung Tugel Banyumas. Jurnal NaturIndonesia 12: 124-129. 